\title{
Abstract not submitted for publication
}

From Food Allergy and Anaphylaxis Meeting (FAAM 2013)

Nice, France. 7-9 February 2013

Published: 25 July 2013

doi:10.1186/2045-7022-3-S3-P108

Cite this article as: : Abstract not submitted for publication. Clinical and Translational Allergy 2013 3(Suppl 3):P108.

Submit your next manuscript to BioMed Central and take full advantage of:

- Convenient online submission

- Thorough peer review

- No space constraints or color figure charges

- Immediate publication on acceptance

- Inclusion in PubMed, CAS, Scopus and Google Scholar

- Research which is freely available for redistribution

Submit your manuscript at www.biomedcentral.com/submit

\section{( Biomed Central}

